\title{
Challenging homophobia in schools: policies and programs for safe school climates
}

\section{Desafiando a homofobia nas escolas: políticas e programas para climas escolares seguros}

\author{
Stephen T. Russell ${ }^{1}$
}

\begin{abstract}
In the United States there has been growing public and scientific attention to homophobia in schools. A well-established body of research documents persistent and pervasive bullying, harassment and lack of safety at schools towards lesbian, gay, bisexual, and transgender (LGBT) students. This work makes clear that contemporary school and youth cultures are characterized by rigid gender and sexuality norms (including homophobia and expectations regarding masculinity, femininity, and heterosexuality); the well-being of students who do not conform to or who challenge these norms is often undermined. In recent years there has been a shift from consideration of the plight of individual students to the acknowledgement that the school context or climate must be better understood in order to prevent bias-motivated bullying and promote school safety and student well-being. During the last decade a number of studies have identified specific education policies, programs, and practices that promote safe school climates. In this article I review what is known about policies and programs that promote safety for LGBT as well as heterosexual students in schools. A growing body of work indicates that the following strategies are associated with safer school climates for LGBT students: enumerated school nondiscrimination and anti-bullying policies; teacher intervention when harassment takes place; availability of information and support about
\end{abstract}

1 Ph.D., is Distinguished Professor and Fitch Nesbitt Endowed Chair in Family and Consumer Sciences in the John \& Doris Norton School of Family and Consumer Sciences at the University of Arizona, and Director of the Frances McClelland Institute for Children, Youth, and Families. 
LGBT concerns for students; the presence of school-based support groups or clubs (often called "gay-straight alliances"); and curricular inclusion of LGBT people and issues. In the context of this research, I discuss several key issues for consideration by educators, policy-makers, and scholars. Keywords: school climate; homophobia; bullying.

\section{RESUMO}

A homofobia nas escolas tem sido foco crescente de atenção científica e do público nos Estados Unidos da América. Um corpo bem estabelecido de pesquisa documenta o bullying, assédio e falta de segurança na escola para estudantes lésbicas gays, bissexuais e transgêneros (LGBT). Este trabalho deixa claro que a escola e as culturas jovens contemporâneas são caracterizadas por normas rígidas de gênero e sexualidade (incluindo a homofobia e expectativas a respeito da masculinidade, feminilidade e heterossexualidade); sendo que o bem estar de estudantes que não se conformam ou desafiam estas normas é muitas vezes prejudicado. Em anos recentes o foco de análise deslocou-se da situação de cada aluno para o reconhecimento de que o contexto e clima escolares precisam ser entendidos melhor para prevenir o bullying motivado por algum viés e promover a segurança na escola e o bem estar dos estudantes. Durante a última década diversos estudos identificaram políticas, programas e práticas educacionais específicas que promovem climas escolares seguros. Neste artigo reviso o que se sabe sobre políticas e programas que promovem a segurança para estudantes LGBT bem como para estudantes heterossexuais nas escolas. Um corpo crescente de trabalhos indica que as seguintes estratégias estão associadas com climas escolares mais seguros para estudantes LGBT: regulamento detalhado de não-discriminação e anti-bullying; intervenção dos professores quando o assédio ocorre; disponibilidade de informação e apoio sobre questões LGBT para os estudantes; presença de grupos de apoio ou clubes com base na escola (frequentemente denominados "alianças gay-hétero"); e inclusão curricular de pessoas e questões LGBT. No contexto desta pesquisa, discuto vários temas chave a serem considerados por educadores, legisladores e acadêmicos.

Palavras-chave: clima escolar; homofobia; bullying.

Recent events in the United States have focused significant public attention and discussion on school safety for lesbian, gay, bisexual, and transgender (LGBT) youth. The murder of 15-year-old Lawrence King in his middle school in 2008 received a high degree of media attention in the country and around the world; King was murdered at school by a boy to whom he had given a valenti- 
ne. A year later, 11-year-old Carl Walker-Hoover committed suicide; his death was attributed to years of daily anti-gay harassment and bullying at school. In the summer and fall of 2010 there were repeated media reports of gay male students (e.g., Asher Brown; Billy Lucas) who took their lives following years of homophobic harassment and bullying. These tragic events represent the most extreme examples of unsafe school climates for LGBT young people. However, these cases are accompanied by hundreds of legal cases related to LGBT issues in schools in the United States (e.g., MERCIER, 2009). Many states and communities, schools and school districts have faced legal action for failing to keep LGBT students safe. In other communities, school districts have fought to keep high school gay-straight alliance clubs (GSAs) or LGBT-inclusive curriculum out of schools. All of this attention has made debate about same-sex sexuality a major issue in public education.

In the context of this public attention, an emerging body of research points to possibilities for promoting the well-being of LGBT students in schools. Until recently, the nearly exclusive emphasis in studies of LGBT youth has been on health risks for individual young people: behavioral risks such as substance use and abuse, and mental health, including depression and suicide risk (RUSSELL, 2005). During the last decade a shift has occurred as scholars have turned from a focus on the problems faced by individual LGBT youth to an attempt to understand the contexts in which youth grow and develop (HORN; KOSCIW; RUSSELL, 2009). Scholars have begun to trace the health risks of LGBT youth to sexual prejudice or homophobia in the key environments that guide their development: their families, peers, schools, and communities. This growing body of research has increasingly supported the proposition that risk, while manifest at the person level, is not a property of the person, but of the family (e.g., RYAN; HUEBNER; DIAZ; SANCHEZ, 2009), peer (e.g., POTEAT; 2008; POTEAT; ESPELAGE; KOENIG, 2009; WICHSTROM; HEGNA, 2003), and school environments (e.g., BOCHENEK; BROWN, 2001; CHESIR-TERAN, 2003; SZALACHA, 2001).

The growing body of research on LGBT youth in schools in the United States has also emphasized risk at the individual student level, emphasizing bullying and harassment at school, and documenting lack of safety (BONTEMPO; D'AUGELLI, 2002; RIVERS, 2001). Yet much of the new work on LGBT youth in schools has begun to focus on characteristics of schools (rather than of LGBT young people themselves) that are associated with risks such as bullying and harassment, as well as student well-being (GOODENOW; SZALACHA, 2003; GOODENOW; SZALACHA; WESTHEIMER, 2006; O'SHAUGHNESSY; RUSSELL; HECK; CALHOUN; LAUB, 2004; SZALACHA, 2003). This focus on schools represents a conceptual shift from individual pathology to the impact 
that school climates have on youth: LGBT youth are not inherently at risk - the environments they grow up in are the problem. From this work a consensus is beginning to emerge: across multiple studies and in multiple geographic settings in the United States, there are several strategies (that is, educational policies, programs, or practices) that have been shown to promote safety and well-being for LGBT youth in schools. These strategies include:

1. School nondiscrimination and anti-bullying policies that enumerate or specifically include actual or perceived sexual orientation or gender identity or expression;

2. Teacher intervention when harassment takes place, and training of teachers on effective intervention strategies;

3. Availability of information, resources, and support at school about LGBT issues;

4. Presence of school-based support groups or clubs (often called "gaystraight alliances" or GSAs); and

5. Inclusion of LGBT people or issues in school curricula.

Research on these strategies is reviewed in the following section. Following this overview, implications of these strategies are discussed, along with several key issues for research and policy related to LGBT students and schools. Finally, the conclusion identifies promising areas for further research and programming to improve student well-being and achievement.

\section{Policies and programs for safe school climates}

In recent years we have learned several important lessons about school safety strategies that make a difference for promoting safe school climates and individual student well-being. Based on a variety of studies, using diverse methods and from multiple locations across the United States and in other countries, researchers have identified several strategies that are important. Each is reviewed below, with attention to remaining questions and directions for further inquiry.

First, inclusive, enumerated nondiscrimination and anti-bullying policies provide the basis for each of the other forms of school safety policy, practice, or programs; enumeration specifically identifies status or identity categories for which discrimination is expressly prohibited. Such policies provide the institutional context for proactive efforts to support LGBT students, and the institutional backing for school personnel (administrators, staff, and teachers) to create and enforce nondiscrimination and anti-bullying measures (RUSSELL; 
MCGUIRE, 2008). A study in California has shown that when students report that their schools have inclusive policies, they feel safer at school and report less anti-LGBT harassment, and they report that their schools are safer for LGBT students. These results hold for LGBT and heterosexual students, but the differences are particularly pronounced for LGBT students (O'SHAUGHNESSY, et al., 2004). The same study demonstrated that students who reported inclusive policies were more likely to report several resilience factors: that students have a voice and can make a contribution at school, and that adults and teachers at the school care. Further, the 2007 National School Climate Survey reported that students who attended schools with comprehensive safe schools policies reported less hostile and more supportive schools: they reported hearing fewer homophobic comments and less victimization or bullying, and more teacher intervention when harassment happened (KOSCIW; DIAZ; GREYTAK, 2008). Finally, studies in Massachusetts documented that LGBT-inclusive school policies were associated with students' assessment of the school diversity climate (SZALACHA, 2003); further students in schools with comprehensive policies report fewer suicide attempts (GOODENOW, et al., 2006).

This new research suggests that inclusive and enumerated school policies make a difference for LGBT student safety; pragmatically, they provide the foundation for the implementation of all other safe school strategies. What is needed now is research on non-enumerated anti-bullying policies; many states and school districts in the United States have non-enumerated policies, and further research is needed to specifically demonstrate whether indeed they are less effective for establishing school climates free of stigma, discrimination, and harassment on the basis of students' race, ethnicity, immigrant status, or actual or perceived sexual orientation or gender identity. In addition to research that documents differences in the types and forms of policies, we need research that explores the ways that policies are established and enacted in educational settings. What is effective in terms of collaboration, communications, or legislative policy for developing support for inclusive, enumerated policies in the first place? Given the variability in state and local legislation and policy regarding LGBT school safety in the United States, a better understanding of the strategies that work in different policy settings is needed, along with knowledge of the most effective strategies for working with decision-makers in these different contexts.

With inclusive policies as a backdrop, the second school safety strategy pertains to school personnel. Several studies have documented the important role that teachers play in the lives of vulnerable students, including sexual minority students (RUSSELL; SEIF; TRUONG, 2001). Beyond the important generally supportive role of teachers, research on LGBT students has shown that teacher intervention in harassment is particularly important. Students feel safer when 
they report that their teachers intervene to stop harassment (O'SHAUGHNESSY, et al., 2004), yet unfortunately students also report that U.S. teachers intervene when slurs are made based on race and gender, and intervene less when slurs are made about sexual orientation or identity (KOSCIW, et al., 2008). Further, a state-wide study in Massachusetts showed that students reported a safer diversity climate in schools in which teachers were trained in violence and suicide prevention related to the experiences of LGBT youth (SZALACHA, 2003). Given this information, we need further work to better illuminate the factors that motivate teachers to be supportive to students and to intervene when harassment takes place. Of course, training of teachers with the skills to intervene is a foundation, and we need to know what would be more effective for this type of training.

A third strategy is the availability of access to LGBT-related resources and support for students at school. Although most students in U.S. schools report that they do not have access to LGBT resources (KOSCIW, et al., 2008), a California study showed that when students report that they know where to go at school for information and support about LGBT issues, they also felt safer personally, and they perceived that their schools were safer for LGBT and gender non-conforming students. They also reported more resilience factors (O'SHAUGHNESSY, et al., 2004).

Student-led school-based organizations and clubs such as gay-straight alliances (GSAs) have grown dramatically in numbers in recent years, and provide students with access to the possibility of direct engagement and action for creating safe and supportive school climates for LGBT students and their allies. GSAs serve several purposes for students: education and safety, interpersonal support, and recreation (GRIFFIN; LEE; WAUGH; BEYER, 2004); they are social spaces where social isolation is reduced in a normative context, that is, a student club (HERDT; RUSSELL; SWEAT; MARZULLO, 2007). This fourth strategy has received notable research attention in the last several years. For example, through GSAs, students create a context for developing positive attitudes towards themselves and others (HERDT, et al., 2007); GSAs have been described and documented as a social space where marginalized youth are empowered to critique and challenge dominant norms for gender and sexuality (RUSSELL; MURACO; SUBRAMANIAM; LAUB, 2009). Multiple studies have clearly shown that the presence of a GSA at school is linked to safety at school for LGBT youth (BOCHENEK; BROWN, 2001; KOSCIW, et al., 2008; LEE, 2002; O'SHAUGHNESSY, et al., 2004; SZALACHA, 2003). Specifically, students in schools with GSAs report fewer homophobic remarks, less harassment and bullying based on sexual orientation or gender identity, were less likely to miss school because of feeling unsafe, and were more likely to feel a sense of belonging to their school environment (KOSCIW, et al., 2008). 
Further, although only a minority of students participate in GSAs in most schools, several studies have shown that simply the presence of the GSA - not necessarily participation in it - is associated with general school safety (GOODENOW, et al., 2006; O'SHAUGHNESSY, et al., 2004; SZALACHA, 2003).

Because of their dramatic growth in numbers during the last decade, GSAs have been the focus of much of the public debate in the United States about LGBT issues in education. In spite of an emerging body of research knowledge, there is still much that we can learn about the role of GSAs in schools. For example, aside from their presence at school, what are the characteristics of GSAs - and of GSA participation - that are meaningful for students and that promote positive adjustment? Some who have fought against GSAs argue that they undermine parental and school authority: does GSA participation make a difference for parent-adolescent relationships - and if so, in what ways? Do GSAs inhibit schools from reaching their educational goals?

Finally, the fifth strategy that has been shown to be effective for creating positive school climates and students well-being is inclusion of LGBT issues in school curricula; it has also been one of the most publicly contentious of the LGBT issues in education. In the last two decades there have been a number of examples of curricular innovations to include LGBT issues across multiple aspects of school curricula, particularly at the high school level (CROCCO, 2001; LIPKIN, 1993, 1999; PERROTTI; WESTHEIMER, 2001; TELLJOHANN; PRICE; POURESLAMI; EASTON, 1995; VAN WORMER; MCKINNEY, 2003). These strategies are said to be beneficial in the curriculum because they prepare students for contemporary democratic society, teach about a topic that because of its public nature is of interest and importance to many students, and because it is personally meaningful and potentially health-promoting for LGBT students, as well as their heterosexual peers (LIPKIN, 1999, 2004).

In addition to work that makes the case for curricular inclusion in the fields of education programs and policy, several empirical studies now document the importance of inclusive or sensitive curriculum for LGBT students. California students who reported that they learned about LGBT issues at school said that their school was safer, and reported less social bullying (mean rumors or lies; being made fun of) and less LGBT bullying (RUSSELL; KOSTROSKI; MCGUIRE; LAUB; MANKE, 2006). Similar to the results for GSAs, students in a national study who reported having learned about LGBT issues at school reported hearing fewer LGBT slurs, less LGBT victimization, more safety, and more supportive conversations with teachers at school (KOSCIW, et al., 2008). Finally, consistent with the argument that LGBT curricular inclusion could promote the health and well-being of LGBT students (LIPKIN, 1999), one study showed that teacher sensitivity to LGBT issues in HIV education has 
been linked to lower sexual risk taking for gay males (BLAKE, et al, 2001). Among the safe schools strategies, this one factor has perhaps the strongest documented influence on multiple student outcomes; further, it is important not only for explaining student well-being, but average differences in school climate indicators as well (RUSSELL, et al., 2006; SZALACHA, 2003).

To date, some scholars and education organizations have made recommendations for inclusion, and there are a number of studies that document positive associations with LGBT curricular inclusion. But what about the curriculum is important? Is it the context or setting in which LGBT issues are learned? The context of LGBT-related education includes a wide range of strategies such as formal classroom subject-matter instruction, school-wide programming, visual materials, or informal teacher-student interactions; surely the relevance and implications of LGBT curricular inclusion might differ across these settings. Further, the content of LGBT education may also vary: history or English lessons, diversity trainings, or school policy programming. Undoubtedly, all of these possibilities should make a difference for promoting school safety climates and student well-being; however, from a policy and practice perspective, further research is needed to identify which dimensions of inclusive curriculum will have the strongest influence on establishing a safe school climate. Answers to these questions will help school administrators and policy makers focus planning and resources in efforts to improve school climates for LGBT and all students.

In summary, there have been important advances in recent years in knowledge of strategies that promote school safety for LGBT students. These strategies have been important grounding for LGBT safe schools advocacy and programming; in addition, they have been the focus of much of the resistance from those who would prefer that LGBT issues remain invisible in schools. Given the importance of this work, and the potential for it to be challenged, there is much that we still need to know.

\section{Future directions}

The research reviewed above provides a basis for educational practice innovation and change to support safe and supportive school environments for LGBT and all students, at least in the context of the United States. Yet there remains much that we do not fully understand. In light of these strategies, two areas in particular deserve further attention, including what we measure as the goals or "outcomes" of safe and supportive educational environments for LGBT 
students, as well as potential differences or distinctive experiences based on other marginal and marginalized statuses (such as race, ethnicity, and social class).

What outcomes? Why?

First, we need conceptual and theoretical discussion and research regarding the end-state that is of concern for LGBT (and all) students. The focus of the research on policies and programs for safe schools for LGBT students has been largely on outcomes such as perceived safety for self and others, and experiences with victimization, harassment, and bullying due to LGBT status. In the larger research literature on LGBT youth we have a strong body of studies of risk (e.g., depression, suicidality, substance use and abuse) (RUSSELL, 2005). Although there is some degree to which these health- and risk-focused questions have made their way into the research literature on LGBT students and schools (BLAKE, et al., 2001; GOODENOW, et al., 2006), we need additional theoretical and empirical work to help us better understand the interconnections between these outcomes of interest as they pertain to the school environment, any that takes seriously yet is critical of why these outcomes are important in the first place. Yet with regard to schools, there has been a greater emphasis on school safety, and less (although some) attention on academic achievement.

Academic achievement is a complex and rich area of study, and includes the multiple and interrelated constructs of not only achievement but academic performance, success, and aspirations. There has been an interest for a number of years in research that would document possibly compromised academic achievement of LGBT students. Obviously, as with the historic focus on mental and behavioral health risk, the impetus here has been to point out that the challenges of growing up in a heterosexist educational culture undermine not only students' well-being, but their academic achievement as well. Yet unlike the body of existing literature on risk and mental health, there is much less documentation that LGBT students have compromised academic achievement. There are surprisingly few studies in this area, yet some empirical evidence does exist. For example, one study documented that boys with same-sex partners had lower verbal IQ (UDRY; CHANTALA, 2002), a measure which likely has less appeal in education studies as it is presumed to be a trait characteristic rather than an educational outcome. However, two other published studies from the same national U.S. survey provide additional evidence. One study used school records and found that same-sex attracted males had lower academic performance than heterosexual males, but that there were no differences for same-sex attracted females (PEARSON; MULLER; WILKINSON, 2007). Finally, a study based on self-reported grade-point average (GPA) found that same-sex attracted youth report lower grades compared to heterosexual youth (the difference was statistically different only for European Americans; African American, Latino, 
and Asian American youth's GPA did not differ based on same-sex attraction) (RUSSELL; TRUONG, 2001); this study did not compare differences based on gender. In summary, there are a small number of studies that suggest that there are possible academic performance and achievement differences for LGBT youth. Further, the studies suggest that gender and ethnicity may be an important factors in the academic experiences of LGBT students; differences appear to be concentrated for same-sex attracted boys, and academic challenges may be more pressing for European American LGBT students.

Given the attention to health and behavior risk, it is surprising that there are so few studies that find evidence of a difference in academic performance for LGBT students. However, it may be that there has not been a clear and strong set of findings regarding LGBT students and academics because young people react to stigma and discrimination in different ways. It is theoretically plausible that navigating stigma will result in compromised emotional wellbeing (e.g., MEYER, 1995, 2003, 2008). We know that individuals react to stress in different ways in terms of their achievement: some become distracted, disengaged, or demoralized, while others turn to academics as a focal point for their coping (and both reactions may be possible for the same young person). Thus, demoralization and disengagement from school on one hand, or vigorous academic focus on the other, are distinct but probable responses to stigmatization for LGBT youth. Complicating this, the same young person may react in different ways in different subjects, or in different contexts: for example, if the classroom is unsafe for learning, over-achievement may not be an option. Further, it may be that stereotypes about (and sometimes characteristics of) LGBT youth promote achievement: for example, the quiet, gender non-conforming boy may be assumed by teachers to be "studious." Thus, perhaps there has been little consistently strong evidence that LGBT young people are doing poorly in school academically because their reactions to hostile climates vary. Studies are needed to trace the reasons why some students manage to do well in spite of having a marginalized status, while others seem to fail academically.

Finally, beyond health and behavior risk and academics there is the possibility for a focus on positive outcomes, or resilience. As indicated above, at least one study has included positive outcomes in addition to factors such as compromised safety and bullying (O'SHAUGHNESSY, et al., 2004). Thus, resilience may be evident as an "outcome" for students. However, it may also be conceptualized as a characteristic of school climate: some schools may promote resilience for students who might otherwise be vulnerable (OLSSON; BOND; BURNS; VELLA-BRODRICK; SAWYER, 2003). For many LGBT youth, a full understanding of resilience should include their ability to access and make use of the setting resources that are available to them. Perhaps even more profound 
are times when students create change in their schools, for example, through student advocacy or activism for school policy change (RUSSELL, et al., 2009).

\section{LGBT and intersecting identities}

A second large area in need of further investigation is the distinctive experiences of the intersections of LGBT identity with race, ethnicity, social class, and other statuses of difference. Additional research and theory could draw from understandings of the experiences of discrimination and oppression based on race, and the ways that research on race and ethnicity can help us understand LGBT youth and their experiences (e.g., MCCREADY, 2004), as well as where the comparison does not apply. For example, one of the points of similarity should be our understanding of minority identities: the classic model of ethnic identity formation is useful for understanding the dimensions of and development of sexual identities in adolescence. On the other hand, racial socialization is a complex set of processes that shape family life for racial and ethnic minority young people, and these processes are known to prepare youth for the navigation of a discriminatory world. Yet most LGBT young people grow up with parents and in families that expect them to grow up to be heterosexual; with rare exceptions, family-based LGBT socialization has not been possible. How do LGBT people learn about the hostilities that exists around them, and (how) do they have a context for understanding that hostility as a characteristic of oppression (rather than of them as individual youth)? Further, attention to the intersections of LGBT identities with race and ethnicity could help us better understand how multiple marginal identities operate in youth's lives: is one identity more salient than others, or is minority stress cumulative? Do the resources and unique strengths of racial socialization or of the ethnic or cultural group provide a protective buffer for LGBT students of color? Such questions prompt us to ask: why would being LGBT be any different for youth of color than it would be for majority youth?

The research on LGBT youth of color is complicated to execute, and has painted a complex picture of LGBT youth of color and their development. In fact, there is some indication that, thanks to racial socialization, LGBT youth of color in the United States may fare better than European American LGBT youth, at least in terms of their emotional health reactions to stigma and discrimination (RUSSELL; TRUONG, 2001). Given that European American youth have made up the majority of most of the population-level studies on LGBT young people in the United States, it may be that our basic understanding of the compromised well-being of LGBT youth is based in part on the fact that European Americans confront stigma and marginalization for the first time when their develop an awareness of their same-sex sexualities. U.S. youth of color, in 
one way or another, have negotiated marginal status all of their lives. Clearly we need additional studies of the development and meanings of same-sex orientation and identities among youth from distinct cultural, racial, and ethnic, economic, and dis/ability backgrounds and settings. We need richer understandings of the meanings of race and ethnicity among LGBT young people in order to begin to understand the implications for education and schooling.

The same is true for gender identity and gender nonconformity. We have only nascent understanding of how gender identities develop, and their implications for young people. We need research that can bridge new psychobiological understandings of gendered development with social/cultural perspectives on childhood and youth. Finally, it is important to acknowledge that the majority of the relevant research has been conducted in the United States, or in a handful of other Western (primarily English-speaking) countries. Western cultures have specific histories and cultures of race, class, and gender; we should not assume that patterns that are evident for students in the United States are necessarily relevant to racialized, class-based, or gendered processes in other cultures. For example, U.S. versions of masculinity and femininity are distinctly rigid; collaborative work across nations and cultures will be important for understanding the ways that conformity to gendered expectations, and the manifestation of gendered identities, are rooted in some combination of culture and human development.

\section{Conclusion}

The recent public attention in the United States to LGBT issues in schools is forcing a discussion of the development of sexual identities, and about whether, when, and how it is appropriate or safe to come out as an adolescent. There is clear indication from the psychological and health sciences that youth should not be forced to hide their sexual identities (AMERICAN ACADEMY OF CHILD AND ADOLESCENT PSYCHIATRY, 2006). Yet more empirical research is needed to helps us better understand the risks - and potential - of coming into an LGBT identity as an adolescent, and of coming out at school. After decades of research on risk, what is now needed is a new field of studies that chart the ways that LGBT youth grow into resilience (RUSSELL, 2005).

In looking to the future, additional research and theory is needed to build our understanding of the complex interplay between individual and environmental risk: that is, we need to understand the realities of the individual experiences of youth - their vulnerability and their agency - at the same time that 
we examine the structural factors that create the contexts for those experiences. Not considered here are the experiences of LGBT parents of school children: this is a virtually uncharted field of study that deserves further attention. The recent shift in focus from "at risk" LGBT youth to a focus on the settings that may produce risk experiences is promising. Yet it is important to maintain a focus on the well-being of individual children and youth: we see the problems of risk as manifest by lost opportunity in the lives of individual young people. Our research must identify methods of change in systems of education and individual support for young people in order to prevent such lost opportunity, and promote the well-being of LGBT and all students.

\section{REFERENCES}

AMERICAN ACADEMY OF CHILD AND ADOLESCENT PSYCHIATRY. Gay and Lesbian Adolescents, 2006. Disponível em: <http://www.aacap.org/galleries/ FactsForFamilies/63_gay_and_lesbian_adolescents.pdf $>$. Acessado em: 1/5/2010.

BLAKE, S. M.; LEDSKY, R.; LEHMAN, T.; GOODENOW, C.; SAWYER, R.; HACK, T. Preventing Sexual Risk Behaviors among Gay, Lesbian, and Bisexual Adolescents: The Benefits of Gay-Sensitive HIV Instruction in Schools. American Journal of Public Health, v. 91, n. 6, p. 940-946, 2001.

BOCHENEK, M.; BROWN, A. W. Hatred in the Hallways: Violence and Discrimination against Lesbian, Gay, Bisexual, and Transgender Students in U.S. Schools. New York, NY: Human Rights Watch, 2001.

BONTEMPO, D. E.; D'AUGELLI, A. R. Effects of at-school victimization and sexual orientation on lesbian, gay, or bisexual youths' health risk behavior. Journal of Adolescent Health, v. 30, n. 5, p. 364-374, 2002.

CHESIR-TERAN, D. Conceptualizing and assessing heterosexism in high schools: A setting-level approach. American Journal of Community Psychology, v. 31, n. 3-4, p. 267-279, 2003.

CROCCO, M. S. The missing discourse about gender and sexuality in the social studies. Theory into Practice, v. 40, n. 1, p. 65-71, 2001.

GOODENOW, C.; SZALACHA, L. Which Schools are Safer for Sexual Minority Adolescents? American Psychological Association, Toronto, Canada, 2003. 
GOODENOW, C.; SZALACHA, L.; WESTHEIMER, K. School support groups, other school factors, and the safety of sexual minority adolescents. Psychology in the Schools, v. 43, n. 5, p. 573-589, 2006.

GRIFFIN, P.; LEE, C.; WAUGH, J.; BEYER, C. Describing roles that Gay-Straight Alliances play in schools: From individual support to social change. Journal of Gay and Lesbian Issues in Education, v. 1, n. 3, p. 7-22, 2004.

HERDT, G.; RUSSELL, S. T.; SWEAT, J.; MARZULLO, M. Sexual inequality, youth empowerment, and the GSA: A community study in California. In: N. TEUNIS; G. HERDT (Orgs.). Sexual Inequalities. Berkeley: University of California Press, 2007. p. 233-252.

HORN, S. S.; KOSCIW, J. G.; RUSSELL, S. T. New research on lesbian, gay, bisexual, and transgender youth: Studying lives in context. Journal of Youth and Adolescence, v. 38 , p. $863-866,2009$.

KOSCIW, J. G.; DIAZ, E. M.; GREYTAK, E. A. 2007 National School Climate Survey: The experiences of lesbian, gay, bisexual and transgender youth in our nation's schools. New York, NY: GLSEN, 2008.

LEE, C. The impact of belonging to a high school Gay/Straight Alliance. The High School Journal, v. Fev/Mar, p. 13-26, 2002.

LIPKIN, A. The case for a gay and lesbian curriculum. The High School Journal, p. 95-107, 1993.

LIPKIN, A. Understanding Homosexuality, Changing Schools. Boulder, CO: Westview Press, 1999.

LIPKIN, A. Beyond Diversity Day: A Q\&A on Gay and Lesbian Issues in Schools. Lanham, MD: Rowman and Littlefield Publishers, 2004.

MCCREADY, L. T. Some challenges facing queer youth programs in urban high schools: Racial segregation and de-normalizing whiteness. Journal of Gay and Lesbian Issues in Education, v. 1, n. 3, 37-51, 2004.

MERCIER, M. T. Fighting to fit in: gay-straight alliances in schools under United States jurisprudence. The International Journal of Human Rights, v. 13, p. 177-191, 2009.

MEYER, I. Social stress and mental health outcomes in lesbians, gay men and bisexuals: Divergences and commonalities in cross-cultural perspectives. International Journal of Psychology, v. 43, n. 3-4, p. 209-209, 2008.

MEYER, I. H. Minority stress and mental health in gay men. Journal of Health \& Social Behavior, v. 36, n. 1, p. 38-56, 1995. 
MEYER, I. H. Prejudice, social stress, and mental health in lesbian, gay, and bisexual populations: Conceptual issues and research evidence. Psychological Bulletin, v. 129, n. 5, p. 674-697, 2003.

O'SHAUGHNESSY, M.; RUSSELL, S. T.; HECK, K.; CALHOUN, C.; LAUB, C. Safe Place to Learn: Consequences of Harassment Based on Actual or Perceived Sexual Orientation and Gender Non-Conformity and Steps for Making Schools Safer. San Francisco, CA: California Safe Schools Coalition, 2004.

OLSSON, C. A.; BOND, L.; BURNS, J. M.; VELLA-BRODRICK, D. A.; SAWYER, S. M. Adolescent resilience: a concept analysis. Journal of Adolescence, v. 26, n. 1, p. 1-11, 2003.

PEARSON, J.; MULLER, C.; WILKINSON, L. Adolescent same-sex attraction and academic outcomes: The role of school attachment and engagement. Social Problems, v. 54, n. 4, p. 523-542, 2007.

PERROTTI, J.; WESTHEIMER, K. When the drama club is not enough : lessons from the Safe Schools Program for Gay and Lesbian Students. Boston: Beacon Press, 2001.

POTEAT, V. P. Contextual and moderating effects of the peer group climate on use of homophobic epithets. School Psychology Review, v. 37, n. 2, p. 188-201, 2008.

POTEAT, V. P.; ESPELAGE, D. L.; KOENIG, B. W. Willingness to Remain Friends and Attend School with Lesbian and Gay Peers: Relational Expressions of Prejudice Among Heterosexual Youth. Journal of Youth and Adolescence, v. 38, n. 7, p. 952-962, 2009.

RIVERS, I. The bullying of sexual minorities at school: Its nature and long-term correlates. Educational \& Child Psychology, v. 18, n. 1, p. 32-46, 2001.

RUSSELL, S. T. Beyond risk: Resilience in the lives of sexual minority youth. Journal of Gay and Lesbian Issues in Education, v. 2, n. 3, p. 5-18, 2005.

RUSSELL, S. T.; KOSTROSKI, O.; MCGUIRE, J. K.; LAUB, C.; MANKE, E. LGBT Issues in the Curriculum Promotes School Safety. Safe Schools Research Brief, n. 4, 2006. Disponível em: <http://www.casafeschools.org/FactSheet-curriculum.pdf $>$.

RUSSELL, S. T., \& MCGUIRE, J. K. The School Climate for Lesbian, Gay, Bisexual, and Transgender (LGBT) Students. In SHINN, M.; YOSHIKAWA, H. (Orgs.), Changing Schools and Community Organizations to Foster Positive Youth Development. Oxford: Oxford University Press, 2008. p. 133-158.

RUSSELL, S. T.; MURACO, A.; SUBRAMANIAM, A.; LAUB, C. Youth empowerment and high school Gay-Straight Alliances. Journal of Youth and Adolescence, v. 38, n. 7, p. 891-903, 2009. 
RUSSELL, S. T.; SEIF, H.; TRUONG, N. L. School outcomes of sexual minority youth in the United States: Evidence from a national study. Journal of Adolescence. Special Issue: Gay, Lesbian, and Bisexual Youth, v. 24, n. 1, p. 111-127, 2001.

RUSSELL, S. T.; TRUONG, N. Adolescent sexual orientation, race and ethnicity, and school environments: A national study of sexual minority youth of color. In: KUMASHIRO, K. K. (Ed.). Troubling intersections of race and sexuality: Queer students of color and anti-oppressive education. New York: Rowman \& Littlefield Publishers, 2001. p. 113-130.

RYAN, C.; HUEBNER, D.; DIAZ, R. M.; SANCHEZ, J. Family Rejection as a Predictor of Negative Health Outcomes in White and Latino Lesbian, Gay, and Bisexual Young Adults. Pediatrics, v. 123, n. 1, p. 346-352, 2009.

SZALACHA, L. A. The sexual diversity climate of Massachusetts' secondary schools and the success of the safe schools program for gay and lesbian students. Dissertation Abstracts International Section A: Humanities \& Social Sciences, v. 62, n. 4-A, p. 1327, 2001.

SZALACHA, L. A. Safer sexual diversity climates: Lessons learned from an evaluation of Massachusetts safe schools program for gay and lesbian students. American Journal of Education, v. 110, n. 1, p. 58-88, 2003.

TELLJOHANN, S. K.; PRICE, J. H.; POURESLAMI, M.; EASTON, A. Teaching About Sexual Orientation by Secondary Health Teachers. Journal of School Health, v. 65, n. 1, p. 18-22, 1995.

UDRY, J. R.; CHANTALA, K. Risk assessment of adolescents with same-sex relationships. Journal of Adolescent Health, v. 31, n. 1, p. 84-92, 2002.

VAN WORMER, K.; MCKINNEY, R. What Schools Can Do to Help Gay/Lesbian/ Bisexual Youth: A Harm Reduction Approach. Adolescence, v. 38, n. 151, p. 409-420, 2003.

WICHSTROM, L.; HEGNA, K. Sexual orientation and suicide attempt: A longitudinal study of the general Norwegian adolescent population. Journal of Abnormal Psychology, v. 112, n. 1, p. 144-151, 2003.

Texto recebido em abril de 2010 .

Texto aprovado em outubro de 2010. 